\title{
RECOVERIES OF SASKATCHEWAN COMMON TERNS
}

\author{
by C. Stuart Houston, 863 University Drive, Saskatoon
}

Although few in number, the recoveries of Common Terns banded in Saskatchewan are of considerable interest for the following reasons:

1. This is the only species which yielded a lower recovery rate from Saskatchewan banding in the 1930's, than from banding since 1950 .

2. This species travels great distances. My first recovery was from the Cook Islands in the southern Pacific Ocean, nearly 3000 miles south of Hawaii and over 6000 miles from Saskatchewan (Houston, 1962), and another reached Costa Rica.

3. One recovery prior to 1950 and one recovery since, were from Minnesota, while all other recoveries outside of Saskatchewan were from the Pacific coast. Further west, the three reported recoveries from early Alberta banding were from the Pacific flyway, two from California and one from Peru (Austin, 1953).

4. The only recovery as an adult at a nesting colony was of a nine-yearold-tern, caught while nesting at old Wives Lake, after having been hatched at Last Mountain Lake. Dr. R. W. Nero and Fred W. Lahrman had a long net placed between a dry-land colony of Western Grebes and the water (Nero, Lahrman and Bard, 1958). The banded tern from an adjacent tern colony became entangled in this net; it was released unharmed after its band number had been recorded.

5. Rapid speed of migration is evident from two terns, still unable to fly in mid-July at Redberry Lake. They were recovered at Malibu, California on October 14 and in Colima, Mexico on October 18 of the same year, after respective travels of 1810 and 2320 miles in less than three months.

6. Vermeer and Reynolds (1970) and Switzer, Lewin and Wolfe (1971), have demonstrated high DDE levels in
Common Tern eggs collected from Alberta and Saskatchewan colonies Their migration routes in relation ts areas of possible pesticide contamina tion thereby become important. Gler A. Fox (pers. comm.) and Switzer Lewin and Wolfe (in press), sugges that the terns in western Canada mas have accumulated high DDE level: on their Pacific wintering grounds If so, "the generally higher DDF residue levels in the eggs of Californis Gulls than in those of Ring-bille Gulls," which Vermeer (1970) postu lated might be due to a difference in diet, would more logically be explaine by the different migration routes 0 the two species. As will be mapped i: future issues of the Blue Jay, the Cali fornia Gull migrates along the mor polluted Pacific coast, as compared $t$ the "cleaner" inland route of the Ring billed Gull.

In addition to the localities men tioned in the list of recoveries below W. I. Lyon banded 47 Common Tern at Redberry Lake in 1937 and I hav banded 24 Common Terns at Goo Spirit Lake, 27 at Quill Lake and 13 at Jackfish Lake, without any recov eries from these localities. The follow ing are the 12 recoveries of Commo Terns banded in Saskatchewan b three different banders: (Note: 514 1043 means $51^{\circ} 40^{\prime}$ North and 104 $30^{\prime}$ West).

Banded by George H. Lang, "Dr Lake" (502-1034); (447 banded) :

Banded July 19/32. Fish net June/3 (4 yr.) One-mile L., Minn. (46 $-0955)$.

Banded by Fred Bard at Last Mour tain Lake 512-1051); (1244 banded):

Banded June 24/40. Injured July $18 / 4$

$(7$ yrs. $)$, Strasbourg, Sask. (510 1045).

Banded July 8/48. Trapped June 21/5 (9 yrs.), Old Wives L., Sask. (50C 1055). 
Banded by C. Stuart Houston at Last Mountain Lake (512-1051); (254 banded) :

Banded July 8/56. Found dead Nov. 26/60 (4 yrs.), Ureia, Aitutaki, Cook Islands $\left(18^{\circ} 50^{\prime}\right.$ South, $159^{\circ} 40^{\prime}$ West).

Banded by C. Stuart Houston at Redberry Lake (524-1071); (1353 banded): Banded June 30/58. Fish net Jan. 15/ 59, Santiago Beach, Colima, Mexico (190-1042).

Banded July 23/61. Found dead July 18/64 (3 yrs.), St. Louis, Sask. (5251054).

Banded July 25/65. Shot Feb. 15/66, Benito Juarez, Guerrero, Mexico 170-1002).

Banded July 9/66. Shot Oct. 18/66, (direct), e. of Tecoman, Colima, Mexico (185-1034).

Banded July 9/66. Found dead Sept. 26/68 (2 yrs.) nr. Hackensack, Minn. (465-0943).

Banded July 16/67. Fish net Oct. 14/
67 (direct) nr. Malibu, Cal. (3401183).

Banded July 16/67. Caught by hand Jan. 19/70 (2 yrs.), Jaco, Costa Rica (093-0843).

Banded by C. Stuart Houston at Dore Lake (544-1070): (23 banded):

Banded July 19/69. Fish net Dec. 28/ 69 (direct), Manzanillo, Colima, Mexico (190-1041).

\section{LITERATURE CITED}

Austin, O. L., Sr. 1953. The migration of the Common Tern in the western hemisphere. Bird Banding, $24: 39-55$.

Houston, C. S. 1962. Common Tern recovery from Cook Islands. Blue Jay, $20: 58-59$.

Nero, R. W., F. W. Lahrman and F. G. Bard. 1958. Dry-land nesting site of a Western Grebe colony. Auk, $75: 347-349$, pl. 15-17.

Switzer, B., V. Lewin and F. H. Wolfe. 1971. Shell thickness, DDE levels in eggs, and reproductive success in common terns in Alberta, Can. J. Zool., 49:69-73.

Switzer, B., V. Lewin and F. H. Wolfe. Effect of DDE on reproductive success in Common Terns at Chip Lake, Alberta. Can. J. Zool. in press.

Vermeer, K., and L. M. Reynolds. 1970 Organochlorine residues in aquatic birds in the Canadian Prairie Provinces. Can. Field-Nat., $84: 1.17-130$.

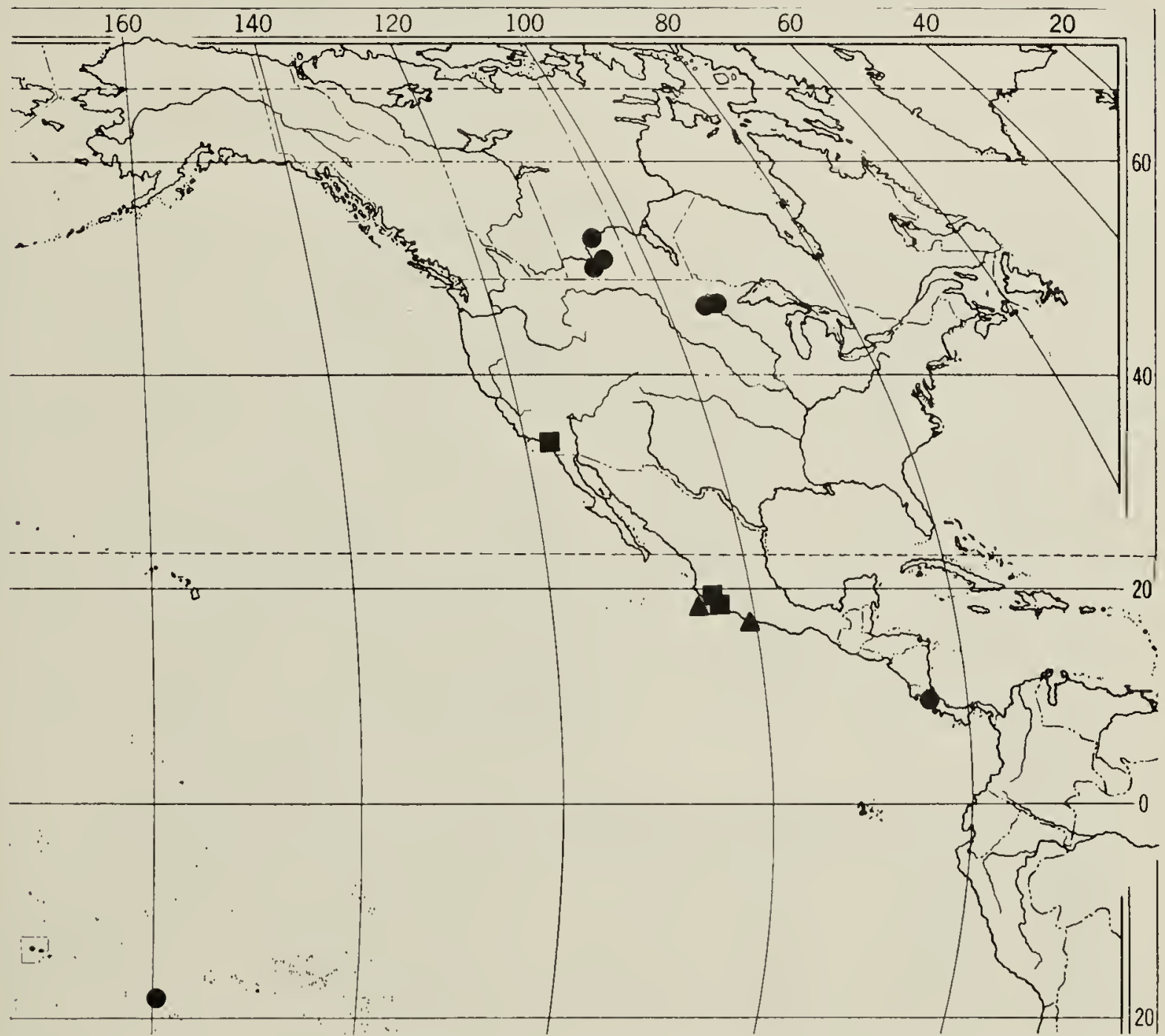

Fig. 1. Recoveries of Common Terns banded in Saskatchewan, 1932. 1971. Note: squares represent direct recoveries (same year) ; triangles, January 1 to June 30 of following year; circles, more than one year old. 